\title{
NATURAL SPECIFIES AND ECOLOGICAL TOURISM AT THE NATURE RESERVE "SLAVKOVSKIY LES" (FOREST NAMED AFTER SLAVKOVSKIY)
}

\author{
Bolshanik P.V. ${ }^{1}$, Kusnezova S.B. ${ }^{2}$ \\ ${ }^{1}$ Omsk State Pedagogical University \\ 2 Yugra State University \\ Corresponding authors: bolschpetr@mail.ru
}

Citation: Bolshanik P.V., Kusnezova S.B. 2020. Natural specifies and ecological tourism at the nature reserve «Slavkovskiy Les» (forest named after Slavkovskiy) // Environmental dynamics and global climate change. V. 11. N. 2. P. 79-87.

DOI: $10.17816 /$ edgcc21261

Text of the article in Russian: https://edgccjournal.org/EDGCC/article/view/21261

In this paper the environmental conditions, the sources, the landscape features of protected territory «Slavkovskiy les» are discussed. The territory is placed on the West of Czech Republic. The review of geographical researches of this region has been given. The main compounds which affect on natural complexes of «Slavkovskiy Les» formation have been characterized. Also a particular consideration is given to characterizing the vegetation and processes of anthropogenic changes of regional landscapes. The main ways of vegetation transformation which had been caused by agricultural activities, plants introduction and changes of runoff pattern have been differentiated. The characteristic of natural areas of preferential protection is proposed. The necessity of «nature reserve» status preservation has been substantiated. A usage of the Natural park for ecological tourism (eco-tourism) is analyzed.

Key words: environmental conditions and sources, landscapes, nature reserves or areas of preferential protection, anthropogenic vegetation transformation.

\section{INTRODUCTION}

During the summer period of 2005, 2007, 2009, 2012, 2015 and 2018 years the field scientific works were conducted by the fellow of Ugra state University. The researches were done in the West part of Czech Republic between two regions: Karlovarskiy and Pilzenskiy. The region is well agriculturally developed. Furthermore, there is a great experience of functioning as an area of preferential protection in the range of protected landscape territories, nature reserves, natural monuments, health and recreation areas.

According to act of nature conservation and landscape in Czech Republic [The Czech National Council, 1992] the areas of preferential protection are the unique areas which have environmental, scientific and aesthetical value. Six categories are distinguished: national parks ( $2 \%$ of all square of Czech Republic), protected landscape territories (13\%), environmental national reserves, nature reserves, national natural monuments and particular natural monuments.

The main resorts of these places are the following: Karlovy Vary, Frantishkovy Lazne and Marianskiye Lazne. They are separated by many kilometers long Slavkovskiy les («Slavkovskiy» translated from Czech language means «nightingale»).

In 1974 the forest was recognized as an area of preferential protection. A unique region is an abundant source of mineral water and gases, peat deposits, different types of landscapes, separately standing peculiar rocks. The Slovkovskiy les as a protected landscape territory contains two national reserves, three national natural monuments, ten nature reserves and twenty natural monuments that have region value.

The basic research aim was a generalization of experience of functioning and development of ecotourism at the area of preferential protection.

The main research objectives consisted in a description of physical-geographic conditions of Slovkovskiy les, observation of the experience of earlier physical-geographic researches of this region. The proper field practices were concentrated on an analysis of anthropogenic vegetation transformation and description of eco-tourism organization.

\section{Materials and methods}

The region of the research (Fig.1) is located on the West of Czech Republic.A configuration of protected landscape territory has a triangle shape which apexes are near the following towns: Karlovy Vary, Heb and Marianskiye Lazne. The square of nature reserve is $610 \mathrm{~km}^{2}$. The Northeastern angle is located near locality Semnize (position: $50.233^{\circ} \mathrm{N}$ and $12.977^{\circ} \mathrm{E}$ ). The Southern boundary is situated near the village Hodova Plana (position: $49.902^{\circ} \mathrm{N}$ and $12.788^{\circ} \mathrm{E}$ ), southwestern point is located near Dolni-Zandov $\left(50.036^{\circ} \mathrm{N}\right.$ and $\left.12.534^{\circ} \mathrm{E}\right)$, northwestern point - near Kinshperi-naOgrzi $\left(50.099^{\circ} \mathrm{N}\right.$ and $\left.12.537^{\circ} \mathrm{E}\right)$. 


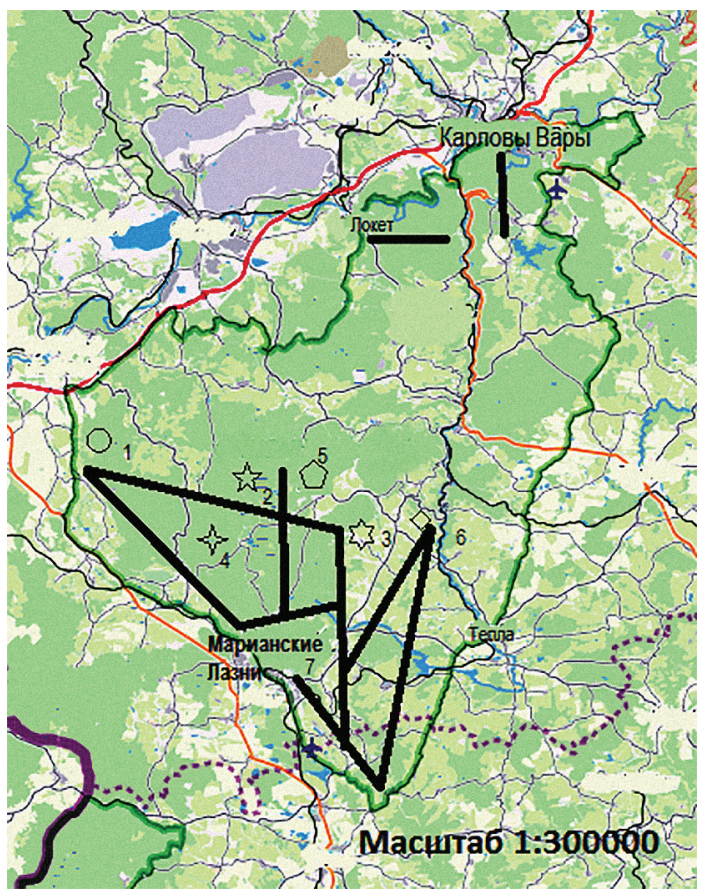

\section{Convention:}

\section{Reservers:}

1. National nature reserve «Kladska»

2. Nature reserve «Smradech»

3. Nature reserve «Vlchek» (Vlček),

4. National natural monument «Lug kupalniz» (Úpolínová louka),

5. National natural monument «Kresty» (Křižky),

6. Nature reserve «Plugov bor» (Pluhy Bor),

7. Marsh swamps and mineral sources of Slavkovskiy les.

black lines - research routes,

green lines - the reserve boundaries,

red and orange lines - transport roads of different traffic, violet lines -the state boarder of Czech Republic,

violet dotted lines - administrative borders

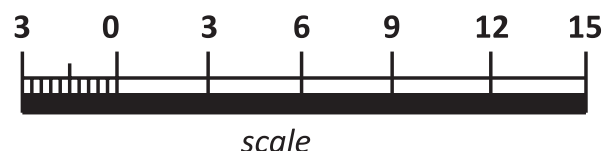

Fis.1. Geographical location of the nature reserve «Slavkovskiy les»

The following field practices have been conducted up to assigned objectives: a floral abundance has been characterized, the reconnoitering routes have been made with photographing the floral species, and the distinctive nature objects have been characterized. The Latin names of plants is given according to GRS (System of Global Resources) [Marianske Lazne].

\section{STUDY SITE}

The nature of Western Czech Republic is well explored. The number of works of natural specifies after Czech and European authors has been published. Geology aspects of the territory, outstanding geological objects and occurrences are represented in the monographs [Batík, 1992; Čejchanová and Cajz, 2009; Chlupáč, 2002; Eder and Patzak 2004; Kühn, 2006; Zouros, 2004]. Specific features of relief forms and major geomorphologic processes are viewed in researches [Kubalíková, 2013; Panizza and Piacente, 2008; Pralong and Reynard, 2005; Reynard et al., 2003; Status of Biological, 2000; Zouros, 2009]. An analysis of reserve management and studies, a development of system of preferential protection areas are written in books [Cílek, 2002, Mackovčin and Sedláček, 2008]. A characteristic of biological resources is viewed in the multi-authored monograph [The Czech National Council, 1992]. A great number of publications [Dowling and Newsome, 2010; Hose, 2000; National Geographic Society, 2005; Panizza and Piacente, 2008; Pásková, 2012; Protected areas in the Czech Republic] is devoted for the analysis of environmental conditions and resources which can be used for tourist and recreation potential of the territory.
The Slavkovskiy les includes a number of preferential protected nature forms and natural monuments. The author has researched the following areas:

- National nature reserve «Kladska» and «Kladskie torphianniki» (Kladské rašeliniště),

- Nature reserve «Smradech» (Smradech),

- Nature reserve «Vlchek» (Vlček),

- National natural monument «Lug kupalniz» (Úpolínová louka),

- National natural monument «Kresty» (Křížky),

- Nature reserve «Plugov bor» (Pluhy Bor),

- Marsh swamps and mineral sources of Slavkovskiy les.

The national natural reserve «Kladska» is a complex of peat rocks which are situated at the height from 800 to 930 meters. It consists of five districts: Taiga, Lysina, Paterak, Maliy Torfiannik and Gus'ev les. A summery square of abovementioned districts is about 270 hectares. In 1977 an ecological path was made around pond «Kladskiy prood». The path is represented by way of wooden flooring over the peat marsh and its length is about $2 \mathrm{~km}$. A route starts near the «Ohotnichiy zamok», rounds the picturesque pond «Kladskiy» and ends in the same place where it starts. Numerous information stands is placed along the path.

The nature reserve «Smradech» got the name due to persistent hydrosulphuric smell. An origin of the smell is related with the peat deposits. Their layers are full of mineral waters and gases. The emission of deep gas forms the mud volcanos. Lake exists among the marsh areas. Lake is formed from 40 sources. The Smradech got status of an area with preferential protection in 1986 and in 1975 it became open for 
visitors. The ecological path is made as the wooden bridge which rises above the ground. An excursion trail has two observation decks. The decks allow viewing the mud volcanos and a water area of lake.A number of rare species of plants have appeared at the reserve territory due to the tectonic and geological specifies.

The nature reserve «Vlchek» is situated on a hill «Vlchi Kamen» $(883 \mathrm{~m})$. It got the status as a nature reserve in 1966. The main object of preferential protection is nature pine forest which grows on serpentine substrate with the peculiar flora. The reserve has an important landscape value. Its main peak makes a landscape landmark. The following plants are seen in the grass cover: the Carnations (Dianthus sylvaticus L.), the Erica rosy (Erica carnea L.) and the Golden Lily (Lilium martagon L.). The Common Lamb can be seen on more dry parts of watershed. The ferns from a sort of Kostenetz (Asplénium) grow in the rocks cracks.

The national nature monument «Lug kupalniz» has a square of 18 ha. It is a complex of typically meadow ecosystem with numerous rare plants species where the first role takes the Globeflower (Trollius apertus Perfil). An international importance of this place firstly assumes the presence of ecosystems related to serpentine. The national value is confirmed by a number of endangered species, for example, the Blueberry willow. This specie had been supposed to be extinct until it was found in these places in 1990 [Status of Biological, 2000].

National natural monument «Kresty» and some surrounding areas distinguish by the peculiar vegetation. Large amount of magnesium penetrates from the subsurface layer (serpentine) into the soil. Thus only the plants adapted to these conditions grow here.A large thickets of the heather (Calluna vulgaris L.) are seen in «Kresty».

Natural and geological reserve «Plugov bor» represents the pine forest which grows on rocky parent material. This material has a great content of serpentine. The rare plants and serpentine deposits are protected here.

«Marsh swamps and mineral sources of Slavkovskiy les» are the Ramsar wetland grounds of global importance. The territory consists of swaps, peat bogs, swampy meadows and mineral sources. On this territory the one of rarest specie of European butterflies dwells, the Checkered Fritillary (Euphydryas aurinia L.), which is an endangered specie.

\section{NATURE RECREATION SOURCES CHARACTERISTICS}

\section{Geological structure and relief}

A formation of Slavkovskiy les occurred in several stages. The most ancient formations are related to hercynian folding. These formations have been metamorphosed and destructed. A rejuvenation of the relief occurred in Alpine orogenesis [Batík, 1992; Čejchanová and Cajz, 2009].

The characteristic manifestations of after volcanic activity is a great number of deposits of hot springs, crystalline laccolithic solids [Chlupáč, 2002] and bathylites, mophins- cracks which forms gases. A form of weathered granite blocks and rocks in shape of mushroom also exists in these places.

All remarkable geological and geomorphological formations are pointed on the tourist maps and characterized in brochures. The asphalted and field roads of good quality bring tourists to them.

Three types of relief are characteristic for geomorphological territory structure: an extensive upland which is covered by peat marshes which presence in Central and Northwestern parts of the region; canyon valleys which are slotted on the corners of upland by the valleys of minor streams (north part of the region, near the town Loket). The third one is gently undulating relief (southeastern part of the territory).

The highest points above the sea level $(983 \mathrm{~m}$ and $982 \mathrm{~m}$ ) are the mountain tops: Lesnaya and Lysina [Reynard et al., 2003]. The minimum height above the sea level is fixed in the location Lipovskiy (460 m) [Kubalíková, 2013].

It is a very geomorphologically eroded upland and has a name similar to the reserve's name. It is mostly generated by granite, gneiss, amphibole [Ecological tourism on a green planet]. In several places the rivers form valleys in shape of canyons which are surrounded by cliffs. Especially these processes are noticeable in the region «Svatoshskie scaly» [Zouros, 2009].

The main objects for recreation, which have been formed on the base of geological and geomorphological resources, are the following: Geological park in Marianskie Lazni; a view point on the hill; an extinct volcano which is the highest point of the upland «Tepel'skaya» (847 m); olivine deposits; the peat marsh with mophets (Fig. 2) (Carbon dioxide and hydrogen sulphide emission); a mountain top «Vilem's».

\section{Climate}

A protected landscape territory is situated mainly in the region of temperate climate (yearly average temperature is within the limit of $6,5^{\circ} \mathrm{C}$ (in Prague this value is about $8^{\circ} \mathrm{C}$ ). However, the sublime parts are related to region with cold climate. The yearly average precipitation total is placed in the interval from 600 to $800 \mathrm{~mm}$ in most of the territory of Slavkovskiy les. The climate in this part is a little bit colder than in most of the territory of Czech Republic due to the fact that it has hilly landscape and western geographical location (nearer to the Atlantic ocean) [Marianske Lazne]. The average duration of the sunshine is 1670 hours per year. 
The snow period is about 120-140 days per year. The mountain territory «Lysinskaya» has the precipitation total in the amount of more than $900 \mathrm{~mm}$ per year [Karlovy Vary Region].

\section{Hydrography}

The most part of Slavkovskiy les is related to the basin «Ogrze». Only minor parts are related to basins of the rivers Mze and Strshela. The nature reserve is slotted by the deep valleys of the rivers Tepla and Ager. The main waterway is the river Tepla which flows from the Northeastern side of the town Marianskie Lazne. In the start it flows to the South-East then Tepla turns to the North near the village and gradually forms deep valley embedded in the relief. After that Tepla flows in the river Ogrze in Karlovy Vary. There it collects water from the mountain sources. An aragonite besieges in the places of water flow from a hot spring. The water flows trickle from the catchment areas of the Ager and the Mze to the Slavkovskiy les. A tiny number of minor streams which are usually nameless are related to the basin of the Mze. These streams are common on border with the upland «Teplezkaya». The river Tepla which flows through the Slavkovskiy les makes wetlands near the village «Sadub-Savishen». It is placed to the Northwest from Marianskie Lazne. The river forms a canyon shaped valley on a short distance between the town Loket and rocks which are toward the West from the town. The main flows in a basin of the Ager which drain the Slavkovskiy contain the river $\mathrm{Li}$ bave and the Lobezskiy stream. A stream of the river Ushoviza also makes a catchment area of the river Mze in the spring. During summer time it loses this touch.

Some channels have the special status of surface waters of Slavkovskiy les. These channels were being used at extraction and recycling of tin ore in the past. One of the most important objects is an artificial channel which was built in 1512-1514 years. The part of artificial structure contains sump ponds that accommodate about $630,000 \mathrm{~m}^{3}$ of water [Cílek, 2002].

The one of the most protected objects is an area of merger of springs. It is used by Western Czech resort centers (Karlovy Vary, Marianskie Lazne, Frantishkovy Lazne, Konstantinovskie Lazne and Lazne Kinzvart). A phenomenon of Slavkovskiy les is hot and cold springs. Water for treatments is taken from the Rudolf's spring, Caroline's spring, Lesnoy, Krestoviy, Ferdinandov's spring, Ambrodgi's and others. Mineral water from the Rudolf's and Maria's source is purchased across the Europe. Mineral water with high magnesium content is delivered by the name «Magnesia». A great number of other mineral springs (Aleksandrin, Medveziy, Bal'binov, Antoninov, Hamelika etc) are situated in the research territory. Some of them are equipped by the way of wells and shallow clefts. Due to a large number of springs in Slavkovskiy les most of the territory is covered by special zones of sanitary protection [Vizer, 2006]. A lot of medicinal resources presences in the resort «Kinzvard». The resort is a part of carbon dioxide water system of Marianskie Lazne. The cold carbon dioxide springs are situated here. Their temperature varies from 7 to $10^{\circ} \mathrm{C}$. The most famous is a Richard's spring which is named after Richard Metternich who was responsible for development of the town «Kinzvard» [Gray, 2013].

Thus, the internal waters are very important for development of balneological tourism in the Western Czech. A lot of water springs is visited by participants of independent tourism. The high quality of springs and significant medical effect make the hydrological objects «the center of attraction» of ecological tourism. The main tourist objects which were based on water resources are: springs Krestoviy, Lesnoi, Caroline's, Rudolf's, Ferdinand's, Ambrodji's, Maliy Medveziy, Bal'binov, Mari's, Piratov, Prelatov, Dratenzkiy, Antoninov; water reservoirs near the Hodovaya Plana and Marianskie Lazne.

\section{Soils}

The genetic types of soils are mostly presented by sod-podzolic and brown forest soils that have been formed on the base of acidic crystalline rocks [Budil et al., 2012].

In the end of last ice age the upper peat lands were formed on the upland of central part of Slavkovskiy les. The most famous are the peat lands in the national reserve Kladska where the largest peat deposits with layers thickness of 7,3 m have been found. In present days the peat deposits are widely used for treatments and pharmaceutical production.

\section{RESULTS}

\section{Flora and fauna of Slavkovskiy les. An anthropogenic modification of the landscapes}

More than a half of Slavkovskiy les square is covered by coniferous, broad-leaved and smallleaved wood species (Fig. 3). The major are pine and spruce forests. On the skirts of these forests the following wood species can be seen: the maples (Ácer platanoídes), the elm trees (Ulmus) and the birch trees (Betula). Sometimes beechen and beech-fir areas are seen [The Czech National Council, 1992]. The above mentioned region was covered by piedmont beech and beech-fir forest in the past but nowadays it has been modified into the firry tree-planting area. The large squares of beech and beech-fir forest have been destroyed in 
the result of crop and treatment of the tin ore. The origin beech forest is preserved on the Western and Southwestern sides of Holina's and Jijkovski's hills. The artificially cultured spruce forests, naturally formed marsh and peat spruce forests are major on the territory. It should be noted that marsh and peat spruce forests which were naturally formed are common in lowlands and play an important part in the reserve. A new habitat of plant variety of the Picea abies has been discovered by the author. This plant variety is «Virgata» (Picea abies (L.) Karst. «Virgata») (Fig.5). According to data of the researcher of the Nature reserve «Slavkovskiy les» this position (position: $49.964^{\circ} \mathrm{N}$ and $12.683^{\circ} \mathrm{E}$ ) is pointed for the first time ever.

Concerning the landscape structure, the temperate mountain landscapes with beech forests on brown forest soils occupy the largest territory of Slavkovskiy les. $30 \%$ of the territory is covered by mountain spruce-fir forests grown on pseudogley or brown forest soils. $10 \%$ is covered by meadow and inundated lowlands on meadow and alluvial soils and by pine forests on brown forest soils.

Naturally formed oak groves grow in the «Lobezskovo» valley. The natural alder (Álnus) and the willow (Sálix) brushes are situated by the river «Teploe». A special role has anthropogenic forests which grow on brushwood storages and uranium mining opencasts. The birches and willows are prevailing in these places and make extensive forests. The largest serpentine complexes in central Europe are placed here. Also the connate pine forests grow here and rare fern species of Asplenium sort, for example, the forked spleenwort (Asplenium septentrionale L.). The heather (Calluna vulgaris L.) and the butterscotch (Iris sibirica L.) at the edge of the forest are highly distributed in these places. Tangles of the cartwheel-flower (Heracleum mantegazzianum Somm. et Levier) can be met by visitors. A great number of seashells and mosses are presented by the sources of sulphurous-carbon dioxide water springs.

Also here are presented the following species: the cow-wheat flower (Melampyrum sylvaticum L.), the deer fern (Blechnum spicant (L.) Roth). Also the houseleek (Ajuga pyramidalis L.) is prevailing here. Besides typical mountain hollows and huge amount of peat lands, a large number of different types of meadows and grasslands are covering the territory of Slavkovskiy les. In inundated forests visitors can meet the Manchurian monkshood (Aconitum variegatum L.) and the common monkshood (the Wolf's bane) (A. septentrionale Koelle). The butterscotch (Iris sibirica L.), the rough gentian (Gentianella obtusifolia subsp. sturmiana) or the pulmonary gentian ( $G$. pneumonanthe L.), the butterfly orchid (Platanthera bifolia (L.) Rich.), the lady's fingers (Digitalis purpurea L.) grow on meadows (Fig.4). The myrtle whortleberry (Vaccinium myrtillus L.) and the mountain cranberry (Vaccinium vitis-idaéa L.) subshurbs and the bog whortleberry (Vaccínium uliginósum L.) are dominant on marshes. In early spring wastelands become covered by the heath bell (Erica carnea L.).

Plants which are under protection are the following: the whortleberry willow (Salix myrtilloides L.), the mountain butterwort (Pinguicula vulgaris L.) and the Drosera Rotundifola (Drosera rotundifolia L.) [Status of Biological, 2000]. Even on the reserve's emblem the rare treatment plant is represented. This plant is the leopard's bane (Arnica montana L.) which grows only in this place.

The cartwheel-flower is an introduced specie which is from the Caucasus. It was introduced in the park «Kinzvard» in the middle of 19 century as a decorative plant. This specie extended along waterways and gradually occupies all wet places in Slavkivskiy les. The cartwheel-flower is actively implements in plant associations and supersedes native species. The plant contains phototoxins [Vizer, 2006].

The fauna is multifarious in forest. Among the animals the major species are the following: the European deer (Cervus elaphus hippelaphus L.), the dappled deer (Cervus nippon T.), the squirrel (Sciurus vulgaris L.), the roebuck (Capreolus capreolus L.), the fallow-deer (Dama dama L.), the foxes (Vulpes vulpes L.), the beech marten (Martes foina Er.), the swine (Sus scrofa L.), and the European badger (Meles meles L.). During winter visitors can meet the European lynx (Lynx lynx L.). Also the black grouse (Lyrurus tetrix L.) habits here. Every year the stork (Ciconia nigra L.) and the eagle-owl (Bubo bubo L.) nestle here. The reserve's special is the fact that this place is the most Western habitat of the ground-squirrel (Spermophilus citellu L.).

Present wide forest complexes with peat lands form the large natural water reservoir which is favorably affects on water regime in this area and especially it has a huge role for resorts. The raised bogs that are characteristic for the Southeastern part of Slavkovskiy les are partly open for visitors and are situated at the ecological trails in regions «Kladska» and «Smradech».

The anthropogenic landscapes transformation occurred by the following ways: 1) deforestation 2) change of surface runoff conditions 3 ) the growing influence of residential, technogenic and recreational factors 4) the introduction of new plants species.

During present time the transformation of vegetation cover is seen. It is caused by anthropogenic recreations pressure. On the elevated landforms near Marianskie Lazne loss of grass cover, soil outcrop and parent rock outcrop occur. This manifestation takes place at the hiking trails. 
Intensive deforestation presented for needs of tin industry, new agricultural area formation, development of residential, recreational, highway and communicational infrastructure. On places of cut down temperate and broad-leaved forests the pine wood species have been landed.

The surface runoff changing occurred in two ways: water accumulation and draining of marshes.

For the accumulation of water resources a huge number of ponds have been formed. Only in $30 \mathrm{~km}$ area around the Marianskie Lazne 29 ponds and water reservoirs have been generated.

The marshes draining presented along the stream «Ushoviza» at the distance of $8 \mathrm{~km}$.

The main tourist sites which are based on biological resources are the following: a city park in Marianskie Lazne, a museum of forestry, an oak alley in a valley of the stream «Hamerskii», a wildlife sanctuary «Hamrinzkaya tryasina», a reservation of peat lands in «Kladska», a nature reserve «Smradech» and a mini zoo.

High diversity of vegetation strengthens attraction of the territory. It is about two factors: the favorable natural conditions and a wide range of works based on the introduction of new species. In 1835 a herbarium from this region contained 512 species, and in present days it contains 986 species according to the data of scientific department of the reserve management.

\section{Ecological tourism}

A huge amount of hiking and ecological trails are set in Slavkovskiy les for the wildlife viewing.
Along forest paths the iron gutters are made at the angle. The gutters prevent paths for being fuzzy by the water flows. Near the peculiar objects the informational desks are generated on Czech language with a translation on German, English and sometimes Russian languages.

All reserve territory is perfectly equipped for tourists: on all routes the pointers, transshipment points, and warning signs are made. The warning signs separate particularly dangerous areas. In several points the suspension bridges are built across the canyons. Deep in the protected landscape territory old dilapidated castles (the fortress under Kinzvard- $50.013 \mathrm{~N}, 12.629 \mathrm{E}$ and the castle «Hodskii» - 49.964 N, 12.694 E) are «hidden». Every castle is supplied by stands with descriptions which are also made in Russian. On the ecological trails tourists can get the information of particular object history and curious facts related to them.

Near the Marianskie Lazne a great number of trails and 14 bicycle routes are made. The bicycle routes crosses all exciting places and goes either on fortified or forest and field roads. The last ones are distinguishing by special markers.

Ecological trails. The ecological trail in the reserve «Kladska» is cleared on special flooring (Fig. 6) where different types of animal and birds tracks are depicted. Also the prints of leaves of commonly occurring plants are seen. Cognitive information is represented on special electronic stands (Fig. 7) that show major species of birds and animals and play their voices. The characteristics of the most popular trails are represented in Table 1.

Table 1. Ecological trails of Slavkovskiy les characteristic

\begin{tabular}{|c|c|c|c|c|c|c|c|}
\hline Path title & $\begin{array}{l}\text { The } \\
\text { length, } \\
\text { km }\end{array}$ & Way of travel & $\begin{array}{l}\text { The complexity of } \\
\text { the terrain }\end{array}$ & $\begin{array}{l}\text { Travel time, } \\
\text { hours }\end{array}$ & Thematics & Stops & $\begin{array}{c}\text { The } \\
\text { amount of } \\
\text { information } \\
\text { desks }\end{array}$ \\
\hline «Kladska» & 1,6 & $\begin{array}{l}\text { On foot, } \\
\text { by bicycle }\end{array}$ & $\begin{array}{c}\text { Simple flat } \\
\text { profile, sand- } \\
\text { gravel roads and } \\
\text { broad walks, the } \\
\text { path is intended } \\
\text { for wheelchair } \\
\text { users }\end{array}$ & $\begin{array}{l}\text { Maximum } \\
1 \text { hour }\end{array}$ & $\begin{array}{c}\text { Botany, } \\
\text { zoology, } \\
\text { hydrogeology } \\
\text { and history }\end{array}$ & 4 & 3 \\
\hline $\begin{array}{l}\text { «nihovskie } \\
\text { smeeviki } \\
\text { (serpentines)» }\end{array}$ & 12 & $\begin{array}{l}\text { On foot, } \\
\text { by bicycle }\end{array}$ & $\begin{array}{l}\text { Simple profile- } \\
\text { forest paths and } \\
\text { roads (the most } \\
\text { energetic part } \\
\text { is on way going } \\
\text { to the road № } \\
210 \text { Prameny- } \\
\text { Mnihov) }\end{array}$ & $3-4,5$ hours & $\begin{array}{c}\text { Botany, } \\
\text { geology and } \\
\text { history }\end{array}$ & 7 & 9 \\
\hline
\end{tabular}


The experience of complex tourism development in Czech Republic is curious. It allows combining the main tourist specialization of the region (balneological tourism) with other types of tourism. It leads to the tourist flow increasing. As an entertainment for holidaymakers short excursion routes of culturalcognitive and ecological tourism are introduced during the decline period of balneological procedures (the weekends). Across the objects of ecological tourism the ecological trails and routes for self-viewing are made. The neighborhood of objects of ecological and sport tourisms (from obstacle course) allows finding an activity for every visitor.

In a children's nature park in the Marianskie Lazne a hydroengineering system is well equipped. At this system working models of water dams, reservoirs, mills etc are represented. Furthermore, sport competition lines for visitors of all ages are generated.

In the town «Marianskie Lazne» the following activities are made: a geological park under the sky, a street exhibition «Natural specifies of Slavkovskiy les» with free entrance, a children nature park; a regional museum where the floristic excursions are conducted. Along the bicycle routes and walking paths a great number of pavilions for recreation, places for sunbathing and places for weekend are built.

However a high diversity of environmental conditions and huge amount of natural recreation objects can't form a narrow specialization for the region which is based on ecological tourism. Only the combination of different types of trip categories makes the great attraction of tourists.

\section{Conclusion}

The geographical description and territory resources of Slavkovskiy les which are basic for ecological tourism development have been determined in the result of the research.

High diversity of landforms and complicated geological history of the territory formation leaded to a huge amount of geological and geomorphologic objects creation. These objects are used in ecological tourism nowadays.

Climate conditions are favorable for recreation activities during the five months and relatively favorable during the rest of year.

High diversity of water objects and presence of numerous underground water outlets form the unique conditions for combination of balneological and ecological tourism.

The conducted researches suggest the well advanced ecological tourism and the expediency of it usage for organization similar reserves and areas of preferential protection in Russia. Creation of electronic stands at ecological trails and organization of sports tourist routes in the recreation park zone deserve the particular interest.

\section{REFERENCES}

1. Визер С. 2006. Славковский лес. Прага: Олимпия. [Vizer S. 2006. Slavkovskiy les. Praga: Olimpiya. (In Russian)].

2. Карловарский край URL: http://gov.cap.ru/home/15/Chez/2. htm (дата обращения: 03.02.2020). [Karlovy Vary Region URL: http://gov.cap.ru/home/15/Chez/2.htm (the date of access: 03.02.2020; In Russian)].

3. Марианские Лазни URL: http://czech-house.ru/marlazni/ fourmarlazni5190.html (Дата обращения: 03.02.2020). [Marianske Lazne URL: http://czech-house.ru/marlazni/fourmarlazni5190.html (the date of access: 03.02.2020; In Russian)].

4. Марианские Лазни URL: http://www.czech-estate.ru/marianske_ lazne/nature (дата обращения: 03.02.2020). [Marianske Lazne URL: http://www.czech-estate.ru/marianske_lazne/nature (the date of access: 03.02.2020; In Russian)].

5. Особоохраняемые территории в Чешской республике URL: https://cyberleninka.ru/article/n/osoboohranyaemye-territoriiv-cheshskoy-respublike (дата обращения: 03.05.2020). [Protected areas in the Czech Republic URL: https://cyberleninka. ru/article/n/osoboohranyaemye-territorii-v-cheshskoy-respublike (the date of access: 03.05.2020; In Russian)].

6. Список растений URL: http://www.theplantlist.org (дата обращения: 03.05.2020). [The Plant List URL: http://www.theplantlist. org (the date of access: 03.05.2020; In Russian)].

7. Черепанов С.К. 1995. Сосудистые растения России и сопредельных государств (в пределах бывшего СССР). СПб.: Мир и семья. 992 с. [Cherepanov S. K. 1995. Sosudistye rasteniya Rossii i sopredel'nykh gosudarstv (v predelakh bysshego SSSR). SaintPetersburg: Mir i Sem'ya. 992 p. (In Russian)].

8. Экологический туризм на зеленой планете URL: https://ecoturizm.net/6626-slavkovskiy-les-v-chehii-zapovednaya-zemlyavozle-kurorta-marianskie-lazne-ch1-2.html (дата обращения: 03.02.2020). [Ecological tourism on a green planet URL: https:// eco-turizm.net/6626-slavkovskiy-les-v-chehii-zapovednayazemlya-vozle-kurorta-marianskie-lazne-ch1-2.html (the date of access: 03.02.2020; In Russian)].

9. Batík P. 1992. Geologická mapa Národního parku Podyjí, Český geologický ústav, Praha // Tourism Alternatives / Smith V., Eadington W. (eds). Philadelphia: University of Pennsylvania Press. P. 31-46.

10. Wimbledon W.A.P., SmithMeyer S. (eds). 2012. Czech Republic // Geoheritage in Europe and its conservation / Oslo: Pro GEO. PP. 92-99.

11. Čejchanová A., Cajz V. 2009. Geologické mapy Českého středohoří Josefa Emanuela Hibsche, Česká geologická služba Praha. Dokořán: Krajiny vnitřní a vnější. 231 p.

12. Chlupáč I. 2002. Geologická minulost České republiky. Academia. 436 p.

13. Cílek V. 2002. Geodiverzita - opomíjený aspekt ochrany prírody a krajiny // Zprávy o geologických výzkumech v roce. V. 13. P. 15.

14. Dowling R., Newsome D. 2010. Geotourism. The tourism of Geology and Landscape. Oxford: Goodfellow Publishers Ltd. 246 pp.

15. Eder F.W., Patzak M. 2004. Geoparks - geological attractions: a tool for public education, recreation and sustainable economic development // Episodes. V. 27(3). P. 162-164.

16. Gray M. 2013. Geodiversity: Valuing and Conserving Abiotic Nature, 2nd edn. Chichester: Wiley Blackwell. 508 pp.

17. Hose T.A. 2000. European Geotourism - Geological Interpretation and Geoconservation Promotion for Tourists // Geological heritage: its conservation and management / Barretino D., Wimbledon W.A.P., Gallego E. (eds). Madrid: Sociedad Geologica deEspaña / Instituto Technologico GeoMinero de España / ProGEO. P. 127-146.

18. Kubalíková L. 2013. Geomorphosite assessment for geotourism purposes // Czech Journal of Tourism. V. 2(2). P. 80-104. 
19. Kühn P. 2006. Geologické zajímavosti Libereckého kraje. Liberecký kraj, resort rozvoje venkova, zemědělství, životního prostředí a informatiky: Liberec. 120 pp.

20. Mackovčin P., Sedláček M. (1999-2008) Chráněná území ČR. Agentura ochrany prírody a krajiny ČR a EkoCentrum Brno // Proceedings of the 11 European Geoparks Conference / Sá A.A., Rocha D., Paz A., Correia V. Arouca: AGA - Associação Geoparque Arouca, 187-188 pp.

21. National Geographic Society. 2005. Geotourism Charter. URL: http://travel. nationalgeographic.com/travel/sustainable/ pdf/geotourism_charter_template.pdf (the date of access: 13.10.2012).

22. Panizza M., Piacente S. 2008. Geomorphosites and geotourism // Rev. Geogr. Acadêmica. V. 2(1). P. 5-9.

23. Pásková M. 2012. Environmentalistika cestovního ruchu // Czech J. Tourism. V. 1(2). P. 77-119.

24. Pralong J.P., Reynard E. 2005. A proposal for a classification

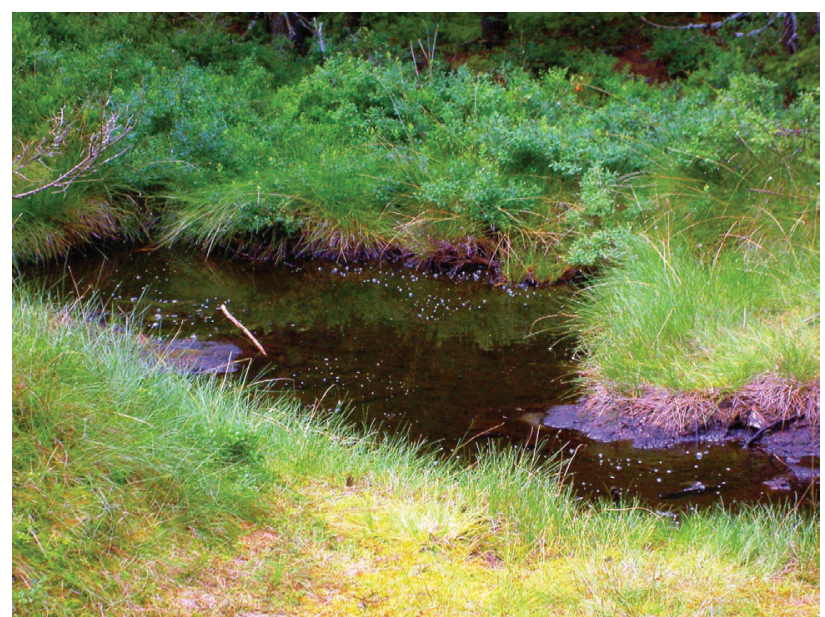

Fí.2. Gas-babbles at the surface of peat land of geomorphological sites depending on their tourist value // II Quaternario - Ital. J. Quat. Sci. V. 18(1). P. 315-321.

25. Holzmann C., Guex D., Summermatter N. (eds). 2003. Géomorphologie et tourisme: quelles relations? // Géomorphologie et tourisme, Actes de la Réunion annuelle de la Société Suisse de Géomorphologie. P. 1-10.

26. Status of Biological Resources and Implementation of the Convention on Biological Diversity in the Czech Republic. First Report. 2000. Prague: Ministry of the Environment of the Czech Republic. 65 p.

27. The Czech National Council Act No. 114/1992 on Protection of Nature and the Landscape. $44 \mathrm{p}$.

28. Zouros N. 2004. The European Geopark Network, Geological heritage protection and local development. Episodes. V. 27(3). P. 165-171.

29. Zouros N. 2009. Geomorphosites within geoparks // Geomorphosites / Reynard E. (ed). Munchen: Pfeil. P. 105-118.

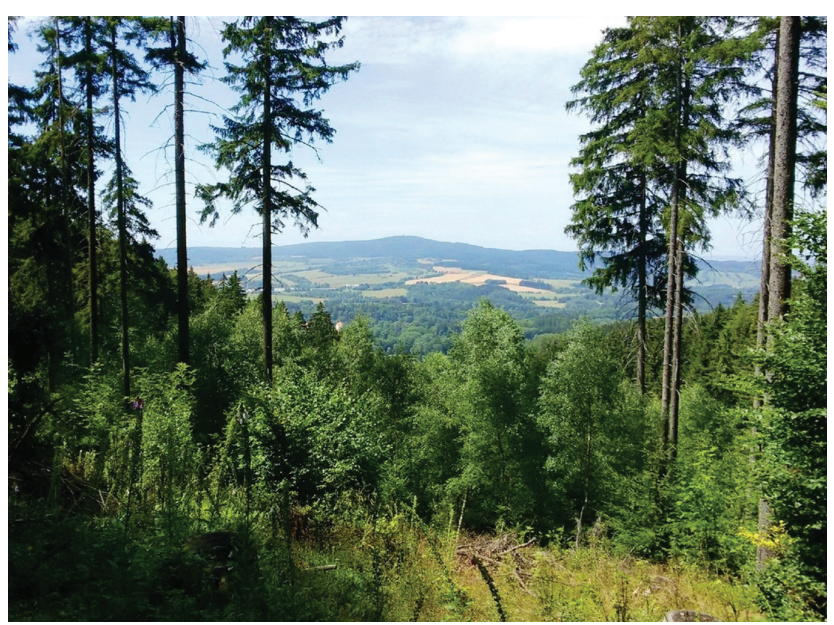

Fis.3. The temperate forest in the Park

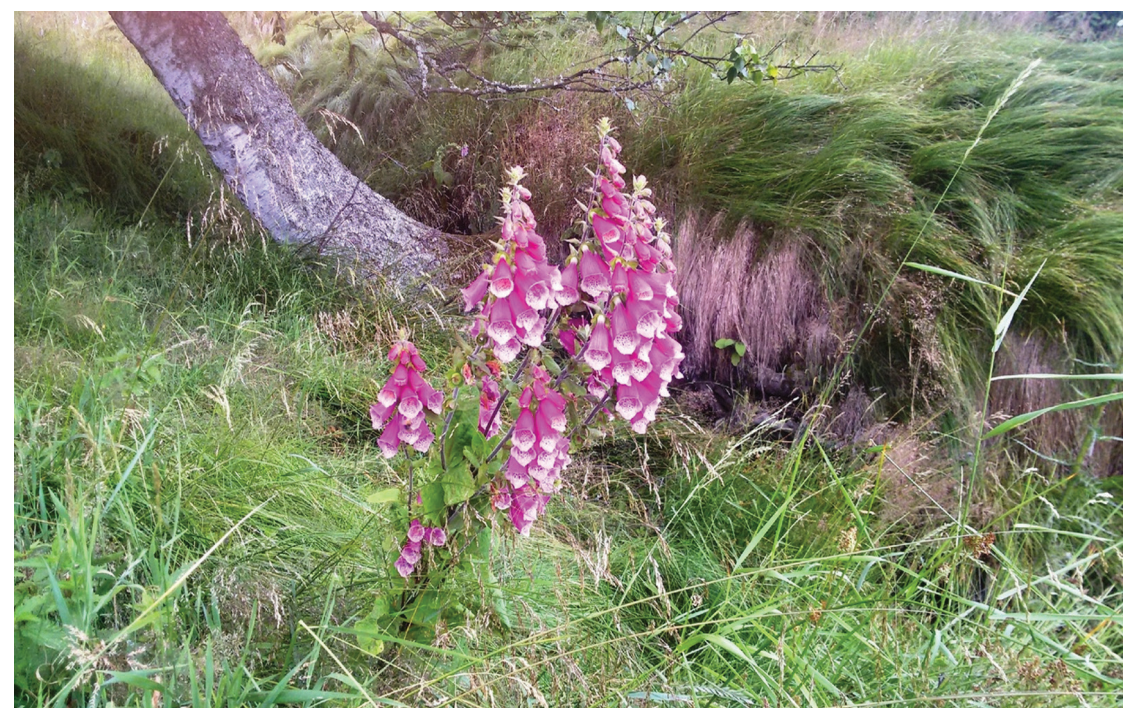

Fiહ.4. The cottagers (Digitális purpurea)

Fís.5. The European Spruce of sort «Virgata» (Picea abies «Virgata») $\rightarrow$

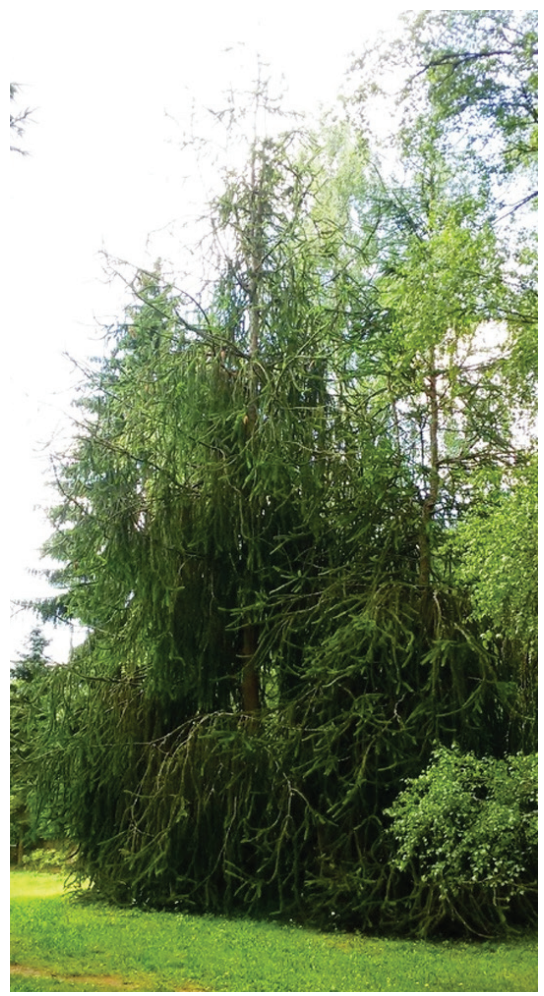




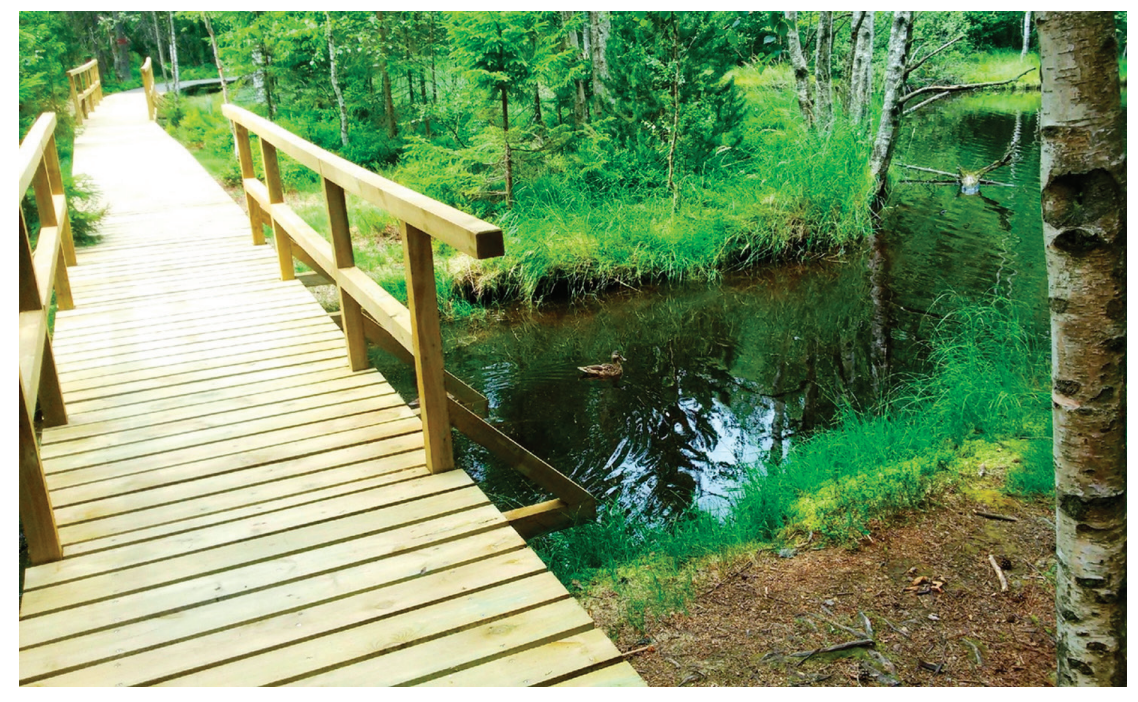

Fis.6. The ecological trail

Fí..7. The temperate forest in the Park $\rightarrow$
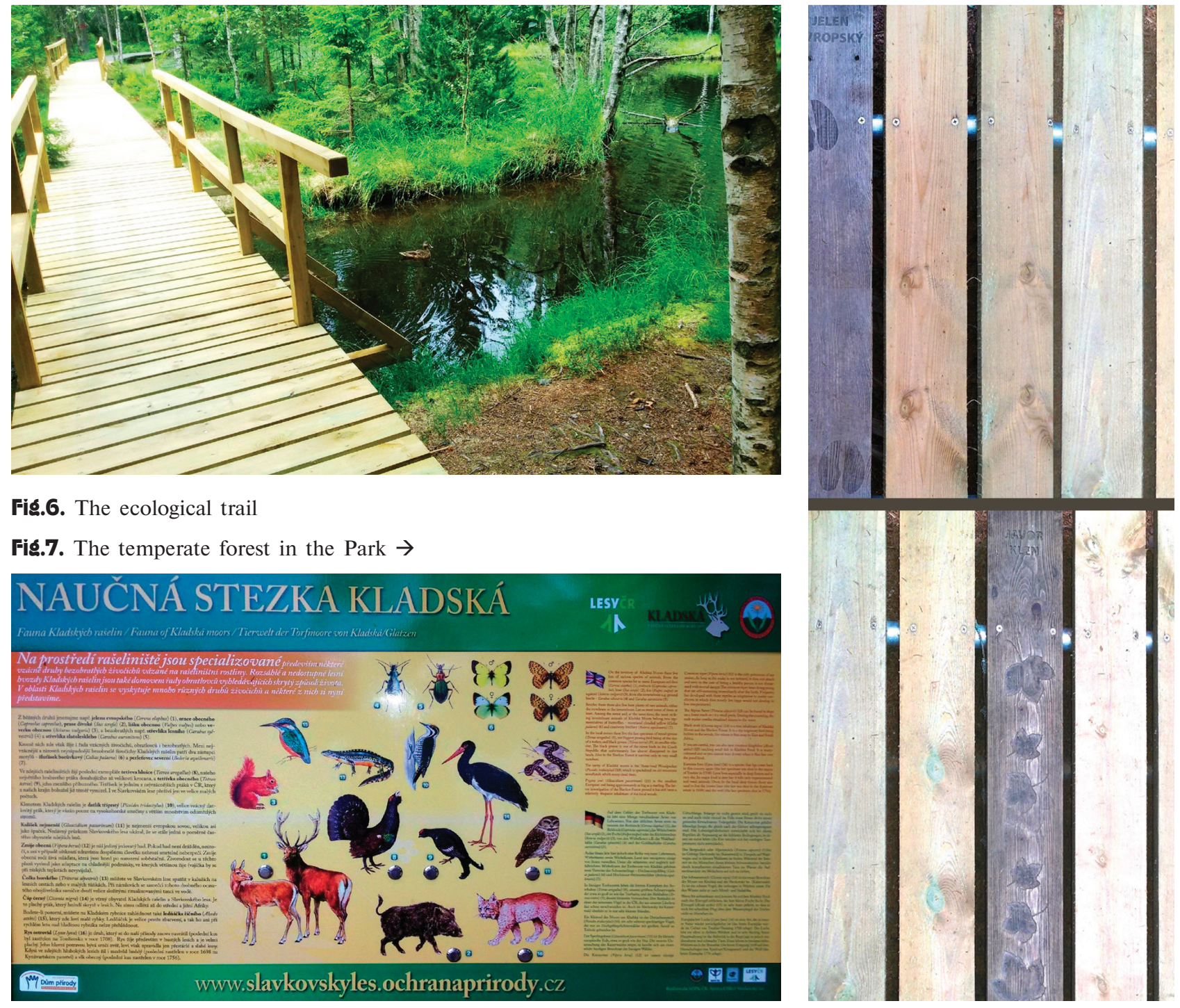

Fiહ.8. A brochure with animal voices records 